\title{
EPISODIC EVENTS ON RADAR AND MULTISPECTRAL REMOTE SENSORS FROM SALAR DE AGUAS CALIENTES, CHILE
}

\author{
A. S, Delsouc ${ }^{1 *}$, M.E. Barber ${ }^{2}$, W. Perez-Martinez ${ }^{3}$, I. Briceño-De-Urbaneja ${ }^{3}$ \\ ${ }^{1}$ Magíster en Teledetección, Escuela de Ingeniería Forestal, Facultad de Ciencias, Universidad Mayor, Chile; \\ analia.delsouc@mayor.cl \\ ${ }^{2}$ Grupo de Teledetección Cuantitativa, Instituto de Astronomía y Física del Espacio (IAFE, CONICET-UBA), Buenos Aires 1428, \\ Argentina.; mbarber@iafe.uba.ar \\ ${ }^{3}$ Hémera Centro de Observación de la Tierra, Escuela de Ingeniería Forestal, Facultad de Ciencias, Universidad Mayor, Santiago \\ 8340589, Chile; waldo.perez@umayor.cl, idania.briceno@umayor.cl
}

KEY WORDS: Sentinel-1, snowfall, flooding, Salar de Aguas Calientes Sur, Chile

\begin{abstract}
:
Restricted episodic changes occurred in a short time period and over large spatial extents. Extreme weather conditions usually give rise to restricted episodic changes. Sentinel-1 radar images of the Salar de Aguas Calientes in Chile acquired in the Altiplanic winter (March 2015 and June 2017), 2018 austral winter and 2017-2018 springtime, demonstrates the ability to monitor episodic events remotely. The results of the backscattered power are encouraging and show episodic variations in VV polarization at C-band. The surface features in Salar de Aguas Calientes Sur change in response to snowfalls during either the Altiplanic or austral winter with an increase of the backscattering in presence of dry snow over the salt pan crust. Flooding events related to snow-melting during spring 2017-2018 showed a decrease in the backscattering signal over ponded water and an increase when wind blows over the water. Remote-sensing observations of the salar can provide a means for monitoring changes in the surface of the salar and a better understanding of the associated climatic episodic event processes. Furthermore, it can help to have a better understanding of environmental changes in arid regions and the understanding of global climate change.
\end{abstract}

\section{INTRODUCTION}

Due to his unique geographical feature, the Salar de Aguas Calientes Sur located at 4,000 m.a.s.l. in the Andes Highlands (Antofagasta region, Chile) has extreme weather conditions which will be addressed in this study by Synthetic Aperture Radar (SAR) images. There, snowfall and rainfall occur either in austral winter (June to September) or in the Altiplanic winter in austral summer (December to March) with $150 \mathrm{~mm} / \mathrm{year}$ average (Risacher et al., 1999). An extreme precipitation event on 24-26 March 2015 impacted over an area exceeding 200,000 $\mathrm{km}^{2}$ and reached $50 \mathrm{~mm}$ precipitation in the Main Andean Range including the Salar de Aguas Calientes Sur (Jordan et al., 2015). Also, in the hyperarid Atacama Desert, Salar de Punta Negra and Pedernales are particularly affected by wind and rain that increases significantly the moisture content of the soil that contributes to groundwater recharge (Scott et al., 2017).

An exceptional flooding event registered by multispectral sensors covers $29.8 \%$ of the Salar de Aguas Calientes Sur in October 2017, and the causes remain unknown (CIREN, 2018). Afterward, intense wind speeds blowing over shallow lagoons controlled the waves' altitude and precipitations of salt (de la Fuente et al., 2016) and, over salars, transportation of salts up to $5 \mathrm{~km}$ distances from the original formation sites are registered (Benison, 2017). Moreover, evaporation, net radiation, and temperature are most significant during the austral summer, but at higher elevations convective cloudiness also develops during January and February reducing both temperature and evaporation rates when significant precipitations may occur, decreasing from 2,000 mm/year in the Atacama Desert to 1,500 $\mathrm{mm} /$ year in the Andes Highlands (Risacher et al., 1999).

On the other hand, unlike rocks, salt pans in the salar are sensitive to changes by wind, evaporation, and dilution by precipitations. Consequently, remote sensing techniques, particularly those using SAR and multispectral imagery, have been proven useful for register surface changes related to episodic events efficiently in terms of time and cost. Changes in roughness and dielectric properties of the salar surface were retrieved from C-band SAR backscattering power (Archer, Wadge, 2001; Aly et al., 2007; Lasne et al., 2007; Lasne et al., 2009; Frison et al., 2013; Paillou et al., 2014). The main advantage of radar systems, unlike optical systems, is its ability to penetrate convective cloudiness developed during January and February over the salar, which allowed capturing information even during the night. Besides, reflectance properties registered by multispectral sensors in visible, nearinfrared (NIR) and short-wave infrared (SWIR) bands are also affected either by moist content or clastic sedimentation in salars (Hung, Wu, 2005; Li et al., 2014; Flahaut et al., 2017). Although previous investigations focused on salars, episodic events as seen by SAR sensors remain unexplored over salars placed in the Andes Highlands where geographical and climatic conditions are distinctive concerning salars placed nearby the sea level.

Already used to understand salar dynamics, SAR data (Sentinel1) can be used in synergy with multispectral images (Landsat 8 OLI and Sentinel-2) as they provide complementary information relative to surface roughness and soil moisture which can be interpreted in terms of episodic events related to extreme weather conditions.

The main goal of this paper is assessing the performance of SAR power response at VV-polarization over the salar surface based on episodic events visually registered in 2015, 2017 and 2018 with Sentinel-2 Multispectral (MSI). This goal is based on the interpretation of the scattering process by relating the backscattering power to snow, wind, and water presence visually interpreted by multispectral sensors.

Corresponding author 


\section{STUDY AREA AND DATA}

\subsection{Study area}

The Salar de Aguas Calientes Sur placed in the Andean high plateau (Antofagasta Region, Chile) has an approximate area of $476 \mathrm{~km}^{2}$, and it is located within the Salar de Talar and the Purisunchi Sub-basin, between Salar de Capur to the west and Laguna Tuyajto to the east (Figure 1). The type of basin is endorheic and intra-volcanic.

To the north and center of the salar are some ignimbrites deposits (Patao Ignimbrite) considered as host rock of the salar from Pliocene age. The south, east and northeast borders are surrounded by alluvial fans that discharge water in the salar depocenter (Ramírez, Gardeweg, 1982). In general, the salt pan crust surface in the center of the salar has no vegetation, whereas the northern, southern, and salar margins are sparsely covered with patchy bushes and spring-feed vegetation related to shallow lakes. The most abundant evaporitic minerals found in the salar are gypsum and halite distributed in two types of salt pan crust; one hard and perennial crust, and the second one perennial or moist and ephemeral either due to the presence of a surface or underground water (Stoertz, Ericksen, 1974).

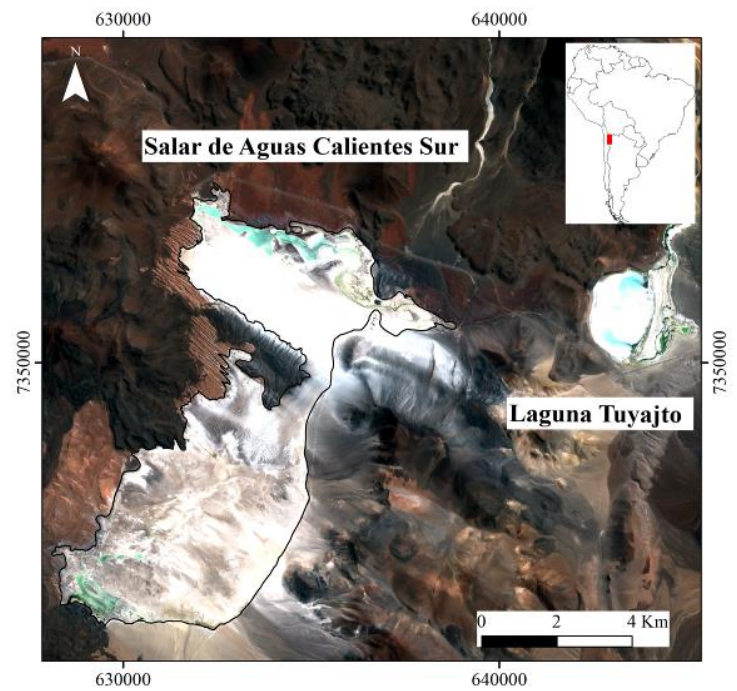

Figure 1. Study area. Sentinel-2B, true colour 432 RGB, 04-03-

2018 showing dry salt pans with high reflectance of salts (white) and lagoons (cyan). (Coordinate system: WGS84-UTM$19 \mathrm{~S})$.

\subsection{Data}

Synthetic Aperture Radar (SAR) Sentinel-1A and B (C-band, $5.55 \mathrm{~cm}$ ), Multispectral Sentinel-2 MSI, and Landsat 8 OLI sensors provided the imagery for this study (Table 1).

Sentinel-1 was acquired in Interferometric Wide Swath (IW) mode, level 1 processing, and Ground Range Detected (GRD). Spatial resolution of $20 \times 22 \mathrm{~m}$ (range by azimuth) and a swath width of $250 \mathrm{~km}$, available in VV polarisation in ascending and descending orbits. For Sentinel-1A/B, the chain process started with orbit correction, thermal noise removal, and radiometric calibration. Subsequently, a Refined Lee filter pixel window of $7 \times 7$ was used to improve radiometric quality of the images. Finally, the geometric terrain correction was applied by assigning the digital elevation model SRTM 1Sec HTG and bilinear interpolation, resulting in an image with a nominal pixel size of $10 \mathrm{~m} \times 10 \mathrm{~m}$. As a final product, output bands of backscattering coefficients $\left(\sigma^{0}\right)$ for Sentinel-1 (VV polarization) in decibels $(\mathrm{dB})$ were generated.
The multispectral data is only intended for a visual interpretation of changes over the salar. Sentinel-2 Multispectral (MSI) was, acquired in level $1 \mathrm{C}, 10 \mathrm{~m}$ of spatial resolution RGB Bands, and Landsat 8 OLI Collection Tier 1 (T1) product, panchromatic at $15 \mathrm{~m}$ of spatial resolution. The pre-processing included DOS (Dark Object Subtraction) atmospheric correction and conversion to Top of Atmosphere (TOA) reflectance. The coordinate system used is WGS84-UTM-19 South.

Table 1. Available radar and multispectral satellite data

\begin{tabular}{|l|l|l|l|}
\hline Sensor & Date & Orbit & Time (UTC-3) \\
\hline Sentinel-1A & $03-28-2015$ & Descending & $10: 16: 01.28$ \\
\hline Landsat-8 OLI & $03-26-2015$ & & $11: 24: 36.29$ \\
\hline Sentinel-1A & $06-08-2017$ & Descending & $10: 16: 01.28$ \\
\hline Sentinel-2B & $06-08-2017$ & & $11: 37: 39.03$ \\
\hline Sentinel-1B & $09-11-2017$ & Ascending & $20: 04: 06.69$ \\
\hline Sentinel-2B & $09-11-2017$ & & $11: 37: 39.03$ \\
\hline Sentinel-1B & $09-07-2018$ & Descending & $09: 50: 15.91$ \\
\hline Sentinel-2B & $09-06-2018$ & & $11: 37: 39.02$ \\
\hline
\end{tabular}

\section{RESULTS AND DISCUSSION}

The dynamic nature of the Aguas Calientes Sur surface, particularly it's northwest and southwest part, had been recognized previously using time series multispectral remote sensing data from Landsat 8 and RapidEye sensors (CIREN, 2018).

Four radar-multispectral pairs were selected to show the spatial distribution of the Salar de Aguas Calientes Sur under different climatic event conditions (Figure 2 and Figure 3). The images illustrated several episodic events over the surface of the Salar de Aguas Calientes Sur and the Laguna Tuyajto and are described below.

\subsection{Snowfall events}

In the autumn of 2015 (March 24-26, 2015), one exceptional snowfall event happened (Jordan et al., 2015), and snow partially covered the salar. The same event was more intense in June 2017, where snow covered the entire salar but not the Laguna Tuyajto. Snowfall events captured by the multispectral sensors Landsat 8 OLI and Sentinel-2, showed high reflectance and white colour in Figure 2 (a, c, e) and Figure 3 (a).

Due to the potential penetration depth in dry snow around $20 \mathrm{~m}$ with SAR C-band (Rees, 2006), the presence of snow registered by Sentinel-1 at VV polarization can be separated into two types interpreted as dry or wet. Figure (b, d, f) and Figure 3 (b) show a clear backscattering coefficient, which allows discriminating between dry snow with backscatter coefficient between $-10 \mathrm{~dB}$ to $-7 \mathrm{~dB}$ (bright patches in the March and June scenes) distributed over the central salt crust pan.

As the snowpack begins to melt, the dielectric properties of the snowpack changes, decreasing the penetration depth of the signal while backscattering reflection from the water table below becomes an increasingly relevant process (Tsai et al., 2019). Consequently, wet snow or snow mixed with spring water distributed in the northwest and southern salt pan crust showed a decrease in backscatter coefficient below $-10 \mathrm{~dB}$ as displayed in Figure 2 (d) by dark grey patches. 

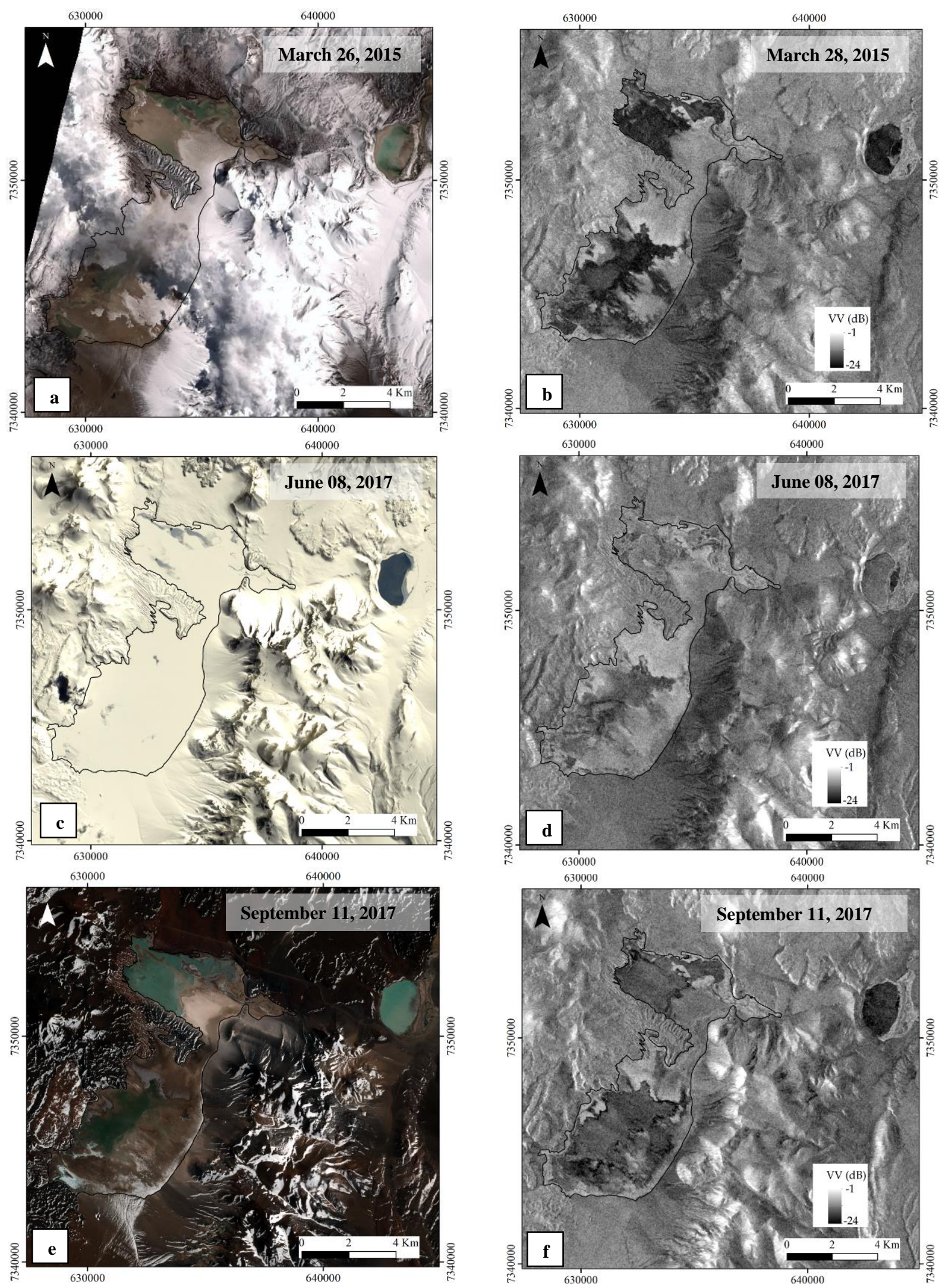

Figure 2. On the left panel multispectral images in true colour 432 RGB are shown. a) Landsat 8 OLI. c) and e) Sentinel-2. Flooded areas are shown in cyan and green. On the right panel, SAR images in VV polarization are shown. Snowfall events are represented on the first and second rows and the flooding event in the last row. 


\subsection{Flooding events}

After the heavy snowfalls, the snow-melting contributes to water table rising several centimetres covering the salt pan crust surface. Flooding event was distributed in the northwest and southwest areas of the salar during September 2017 and 2018, as seen in Figure 2 (e, f) and Figure $3(\mathrm{a}, \mathrm{b})$, respectively. Sentinel-2 showed ponded water in cyan and green, while moisture in the salt pan crust related to decreasing in roughness can be seen in light-brown colour in 432 RGB. For Sentinel$1 \mathrm{~B}$, the flooded areas were clearly recognized since it appears in dark with less than $-20 \mathrm{~dB}$ due to the lowest backscatter and specular reflection from the pounded water bodies on September 7, 2018. However, the opposite effect happens when flooding events are deeply influenced by occurrence of an active and unidirectional northwest-southeast wind regime seen as parallel line patterns over the water surfaces, which also increase the waves on the water surface and alters the backscattering power (Bian et al., 2018) rising to $-12 \mathrm{~dB}$. Figure 2 (b, d, f) shows these events differentiated in the Laguna de Tuyajto and Salar de Aguas Calientes Sur ponded water.
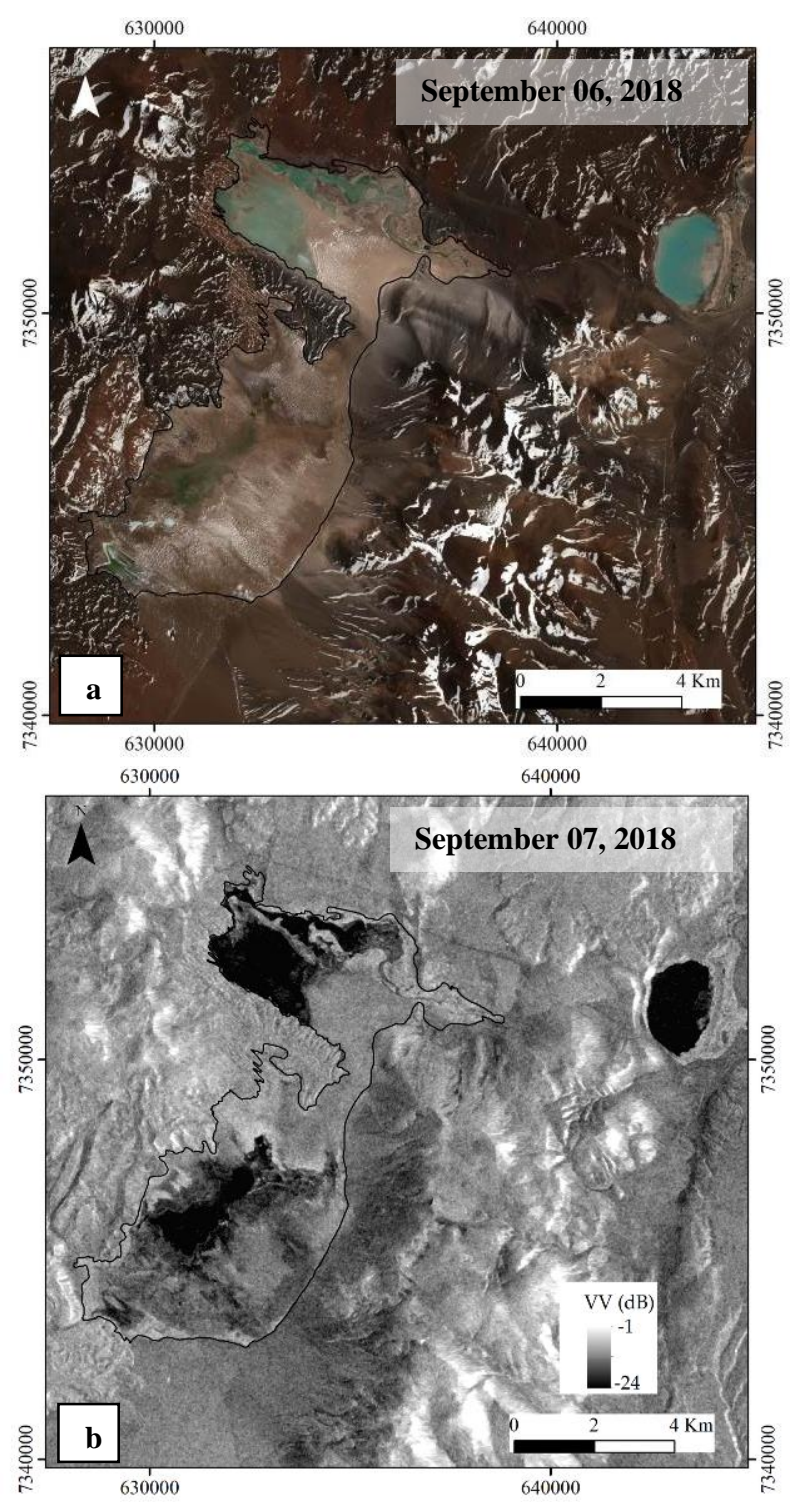

Figure 3. a) Sentinel-2. Flooding b) Sentinel-1B. Flooding event is represented by dark areas of low backscattered power.
Acquisitions show than an extreme flooding event happened on September 11, 2017, covered areas of $3.14 \mathrm{~km}^{2}$ in Laguna Tuyajto and $26.23 \mathrm{~km}^{2}$ in the Salar de Aguas Calientes Sur as seen in Figure 2 (f). On the other hand, the flooding on September 6, 2018 (Figure 3), covered minor areas of $2.79 \mathrm{~km}^{2}$ in Laguna Tuyajto and $9.52 \mathrm{~km}^{2}$ in Salar de Aguas Calientes Sur. The differences between water income in both years are related to frequency and intensity of snowfalls, suggesting that during winter 2017, precipitations were stronger compare with 2018 winter season (Delsouc et al., 2020).

\section{CONCLUSIONS}

The Salar de Aguas Calientes Sur is a vast evaporitic environment that was used as a benchmark to evaluate the potential of SAR remote sensing for the monitoring of dynamics related to episodic events. The backscattering power resulted profoundly affected by snowfalls, flooding and wind events, mainly in the northwest and southwest depocenters. Consequently, dramatic changes in both dielectric constant and roughness state between dry and wet conditions over the salar. On the other hand, visual interpretations of the events with multispectral sensors resulted in significant support in order to complement the information. A more in-depth quantitative analysis of these preliminary observations shall be conducted in the future. A seasonality analysis will require an extensive temporal set of the SAR backscatter power to investigate frequency of changes.

\section{REFERENCES}

Aly, Z., Bonn, F. J., Magagi, R., 2007: Analysis of the backscattering coefficient of salt-affected soils using modeling and RADARSAT-1 SAR data. IEEE Transactions on Geoscience and Remote Sensing, 45(2), 332-341. https://doi.org/10.1109/TGRS.2006.887163

Archer, D. J., Wadge, G., 2001: Modeling the backscatter response due to salt crust development. IEEE Transactions on Geoscience and Remote Sensing, 39(10), 2307-2310. https://doi.org/10.1109/36.957294

Benison, K. C., 2017: Gypsum gravel devils in Chile: Movement of largest natural grains by wind? Geology, 45(5), 423-426. https://doi.org/10.1130/G38901.1

Bian, X., Shao, Y., Wang, S., Tian, W., Wang, X., \& Zhang, C. 2018: Shallow Water Depth Retrieval From Multitemporal Sentinel-1 SAR Data. IEEE Journal of Selected Topics in Applied Earth Observations and Remote Sensing, 11(9), 2991-3000. https://doi.org/10.1109/JSTARS.2018.2851845

CIREN, 2018. Provisión de imágenes satelitales y ejecución de un estudio de geoprocesamiento para caracterización de salares. Comisión de Minería No Metálica- Centro de Información de Recursos Naturales, Inédito.

de la Fuente, A., Ordóñez, C., Pérez, R., 2016: Diffusional mass transfer coefficient at the water-sediment interface for wind-induced flow in very shallow lagoons. Environmental Fluid Mechanics, 16(3), 539-558. https://doi.org/10.1007/s10652-015-9437-9

Delsouc, A., Barber, M., Gallaud , A., Grings , F., Vidal-Páez, P., Pérez-Martínez, W., Briceño-De-Urbaneja, I., 2020: Seasonality analysis of Sentinel-1 and ALOS2/PALSAR-2 backscattered power over Salar de Aguas Calientes Sur, Chile. Manuscript Submitted for Publication.

Flahaut, J., Martinot, M., Bishop, J. L., Davies, G. R., \& Potts, 
N. J., 2017: Remote sensing and in situ mineralogic survey of the Chilean salars: An analog to Mars evaporate deposits? Icarus, 282, 152-173. https://doi.org/10.1016/j.icarus.2016.09.041

Frison, P. L., Paillou, P., Sayah, N., Pottier, E., \& Rudant, J. P., 2013: Spatio-temporal monitoring of evaporitic processes using multiresolution C-band radar remote sensing data: Example of the Chott el Djerid, Tunisia. Canadian Journal of Remote Sensing, 39(2), 127-137. https://doi.org/10.5589/m13-018

Hung, M. C., \& Wu, Y. H., 2005: Mapping and visualizing the Great Salt Lake landscape dynamics using multitemporal satellite images, 1972-1996. International Journal of Remote Sensing, 26(9), 1815-1834. https://doi.org/10.1080/0143116042000298324

Jordan, T., Riquelme, R., González, G., Herrera, C., Godfrey, L., Colucci, S., ... Ramos, H., 2015: Hydrological and geomorphological consequences of the extreme precipitation event of 24-26 March 2015, Chile. XIV Congreso Geológico Chileno, La Serena, Chile, (March), $2-5$.

Lasne, Y., Paillou, P., Ruffié, G., Serradilla, C., Demontoux, F., Freeman, A., ... Malézieux, J. M., 2007: Effect of salinity on the dielectric properties of geological materials: Implication for soil moisture detection by means of remote sensing. International Geoscience and Remote Sensing Symposium (IGARSS), 3689-3693. https://doi.org/10.1109/IGARSS.2007.4423644

Lasne, Yannick, Paillou, P., Freeman, A., Farr, T., McDonald, K., Ruffié, G., ... Chapman, B., 2009: Study of hypersaline deposits and analysis of their signature in airborne and spaceborne SAR data: Example of death valley, California. IEEE Transactions on Geoscience and Remote Sensing, 47(8), 2581-2598. https://doi.org/10.1109/TGRS.2009.2014862

Li, J., Menenti, M., Mousivand, A., \& Luthi, S. M., 2014: Nonvegetated playa morphodynamics using multi-temporal landsat imagery in a semi-arid endorheic basin: Salar de Uyuni, Bolivia. Remote Sensing, 6(10), 10131-10151. https://doi.org/10.3390/rs61010131

Paillou, P., Sufyar, S., \& Freeman, A., 2014: The Chott El Djerid, Tunisia: Observation and discussion of a SAR Phase signature over evaporitic soils. IEEE Transactions on Geoscience and Remote Sensing, 52(9), 5798-5806. https://doi.org/10.1109/TGRS.2013.2292822

Ramírez, C., \& Gardeweg, M., 1982: Hoja Toconao. Servicio Nacional de Geología y Minería, Carta Geológica de Chile, $N^{\circ} 54$.

Rees, W. G., 2006: Remote Sensing of Snow and Ice. FL, USA: CRC Press: Boca Raton.

Risacher, F., Alonso, H., \& Salazar, C., 1999: Geoquímica de aguas en cuencas cerradas: I, II y II Regiones-Chile.

Scott, C. P., Lohman, R. B., \& Jordan, T. E., 2017: InSAR constraints on soil moisture evolution after the March 2015 extreme precipitation event in Chile. Scientific Reports, 7(1), 1-9. https://doi.org/10.1038/s41598-01705123-4

Stoertz, G. E., \& Ericksen, G. E., 1974: Geology of Salars in Northern Chile. In Geological survey professional paper.

Tsai, Y. L. S., Dietz, A., Oppelt, N., \& Kuenzer, C., 2019: Remote sensing of snow cover using spaceborne SAR: A review. Remote $\quad$ Sensing, $11(12)$. https://doi.org/10.3390/rs11121456 